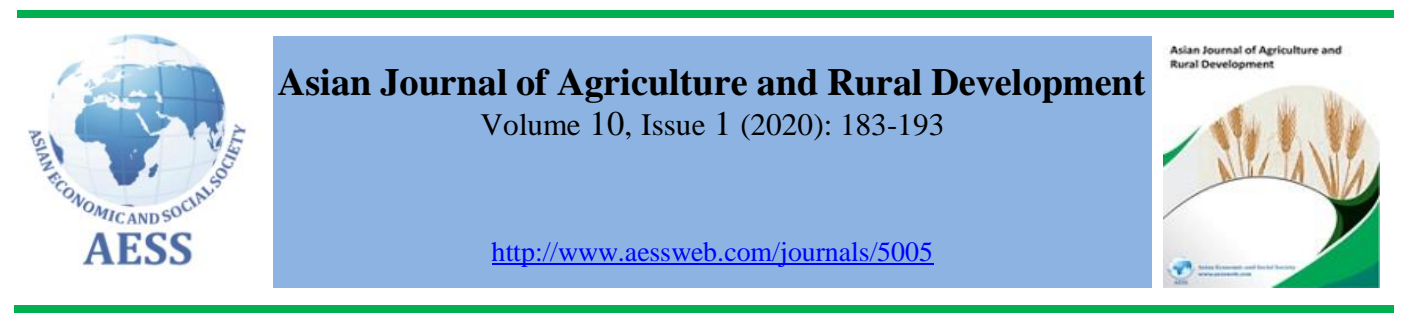

\title{
SPATIO-TEMPORAL CHANGES IN THE PATTERNS OF MALE AND FEMALE AGRICULTURAL LABOUR IN PUNJAB: A GEOGRAPHICAL ANALYSIS
}

Sucha Singh
Assistant Professor; Department of Geography, University School of Open Learning, Panjab University, Chandigarh, India

suchasahota@gmail.com; suchasingh@pu.ac.in

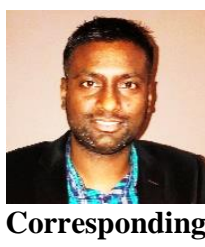

author

\section{ARTICLE HISTORY:}

Received: 16-Jan-2020

Accepted: 30-Mar-2020

Online Available: $27-\mathrm{Apr}-$ 2020

\section{Keywords:}

Agricultural labour, Farm operations,

Farm mechanization, Non-farm sector,

Scheduled castes population, Vegetable farming

\begin{abstract}
The present paper attempts to examine the Spatio-temporal changes in the distribution patterns of male and female agricultural labour at tehsil level in Punjab. This study assumes importance given the significant decline in both male and female agricultural labour in the state particularly after the implementation of the new economic policy in India in 1991. The data on agricultural labour for census years of 1991 and 2011 collected from Primary Census Abstracts. The analysis concluded that vast areas of the state namely central plains followed by northeast sub-mountainous have recorded a decrease in the proportion of female agricultural labour which was more than their male counterparts during 1991-2011. The major reason behind the decline in female agricultural labour has been mechanization of farm operations while casualization of work in agriculture and shift of labourers from farm to better paid non-farm sectors led to the decline in male agricultural labour in the state. The most important suggestions came in the form of formulating a policy to absorb the displaced male and female labour in non-farm occupations through area-specific short term skill programs as well as implementing state's crop diversification plan for engaging less skilled females in the cultivation of labour intensive and high income earning vegetables farming in Punjab.
\end{abstract}

\section{Contribution/ Originality}

The research paper identifies areas where a steep decline in male and female agricultural labour has been recorded in Punjab during the study period of 1991-2011. In the absence of census studies at tehsil level, the present research paper provides information for formulating an area-specific policy on absorbing displaced agricultural labour by adopting suggested measures at the grass-root level in the state.

DOI: 10.18488/journal.1005/2020.10.1/1005.1.183.193

ISSN (P): 2304-1455/ISSN (E):2224-4433

How to cite: Sucha Singh (2020). Spatio-temporal changes in the patterns of male and female agricultural labour in Punjab: A geographical analysis. Asian Journal of Agriculture and Rural Development, 10(1), 183-193. 


\section{INTRODUCTION}

Agricultural systems practised around the world have different combinations of labour and capital inputs. The mechanisation of practices has greatly reduced the amount of farm labour especially in the developed countries of the world. But in the underdeveloped countries, the labour input is still very high. In these countries, the replacement of traditional agricultural practices by mechanised practices of farming has a considerable impact on employment. In India, there is also a substantial shift of the surplus rural workforce from agriculture to non-farm sectors since 1991.

After July 1991, under the New Economic Policy (NEP), the agriculture sector of India has experienced a different type of change. The reforms have opened up trade in agriculture and have given a boost to exports. The policy favoured the large farmers with the capital to buy new technology in the form of mechanization and those with the ability to switch to the production of higher-priced cash crops over food crops (Sahay, 2010). The losers include the small farmers and landless labourers whose incomes declined as a result of mechanisation. Employment in agriculture showed a negative trend during the post reforms period (Chand et al., 2017). The percentage of people employed in agriculture has been consistently declining, from around 60\% in 1999-00 to $49 \%$ in 2011-12 during NSSO $68^{\text {th }}$ Round (FICCI, 2015). In terms of casual labour in agriculture, both rural males and females registered a decline in their share from $27.7 \%$ and $35.6 \%$ in 1993-94 of NSSO $50^{\text {th }}$ Round to $20 \%$ and $26.4 \%$ in $2011-12$ of NSSO $68^{\text {th }}$ Round in the country respectively (Usami and Rawal, 2018). The rural male population employed in agriculture has seen a decline of 12 percentage points from $67 \%$ to $55 \%$ while the same witnessed a spike in the manufacturing sector by 8 percentage points from $15 \%$ to $23 \%$ during 2005 to 2018 in India (Gupta, 2019). The NSO Periodic Labour Force Survey 2017-18 has also recorded the gradual shift of surplus rural workforce particularly youth from agriculture to the non-farm sector in the country, due to low wages and irregular employment (GOI, 2019; Chand, 2019).

In Punjab, the adoption of new agricultural technology under the name of Green Revolution in the mid-1960s and the new economic policy of 1990s led to the mechanized intensive cultivation of mono-cropping (mainly wheat and paddy cycle) instead of multiple cropping which has largely affected the agricultural labour in the state of Punjab (Billings and Singh, 1970; Grewal and Kahlon, 1974; Randhawa, 1974; Johl, 1975; Laxminarayan, 1982; Chadha, 1986; Sidhu, 1991; Singh, 1995; Bhalla and Singh, 2001; Rangi and Sidhu, 2004; Sidhu and Singh, 2004; Kaur, 2005; Sidhu et al., 2005; Husain, 2006; Dutta, 2012; Narayanamoorthy et al., 2014; Prasad and Kaur, 2017; NABARD, 2018; Rathi, 2020). The rapid capitalisation of agriculture in Punjab has resulted into the displacement of labour from traditional employment in certain farming operations and transference of workforce from agriculture to the non-agriculture sectors (Visaria and Basant, 1994; Singh, 1995; Kumar, 1996; Bhalla and Singh, 2001; Gill and Ghuman, 2001; GOP, 2004; Ghuman, 2005; Kaur, 2005; Husain, 2006; Singh et al., 2007; Toor et al., 2007; Jodhka, 2008; Institute of Applied Manpower Research, 2013; FICCI, 2015; Singh, 2016; Rathi, 2020). Presently, the agricultural sector of the Punjab state has been passing through the phase of declining employment. The agricultural labour has been rising until 1991 but the share of agricultural labourers has declined significantly from 1991-2011 (Table 1).

Table 1: Percentage share of agricultural labour in Punjab

\begin{tabular}{lccccc}
\hline Year & $1970-71$ & $1980-81$ & $1990-91$ & $2000-01$ & $2010-11$ \\
Agri. labourers & 20.11 & 22.16 & 23.82 & 16.3 & 13.82 \\
\hline
\end{tabular}

Source: Census of India (1970-71 to 2010-11)

Now, the mechanization has led to the greater employment of casual labour in the agricultural operations only during the peak periods of wheat and paddy crops (Singh, 2009; Singh, 2012; Reddy et al., 2014; Raju et al., 2015; Rathi, 2020). The recent pattern of labour employment has 
created a paradox of scarcity and surplus of labour in the state (Kaur et al., 2018). During the sowing and harvesting periods, there is a sudden spurt of activity and consequently, the need for labour increases considerably. In recent times, the low availability of labourers is threatening the sowing and harvesting operations of agriculture in the state (Dheer, 2012; Singh, 2012; The Business Standard, 2013; Chaba, 2014; Narayanamoorthy et al., 2014; Singh, 2015; Singh and Bhogal, 2016; Sood, 2016; Bhardwaj, 2017; Gill, 2018; NABARD, 2018; Sharma, 2018; Bajwa, 2019; Bajwa, 2019).

In light of the above changes in labour absorption in the agriculture sector of Punjab, the present research paper has examined the Spatio-temporal changes in the distribution patterns of male and female agricultural labour at tehsil level during 1991 and 2011 Censuses in the state.

\section{DATA SOURCES AND METHODOLOGY}

An extensive literature survey has revealed that most studies on agricultural labour have been conducted from the social and economic point of view. There is hardly any research study on the change of agricultural labour at tehsil level on census data from a geographical point of view in Punjab. Therefore, the present research is entirely based on census data.

Indian census provides a wide range of population data, where decennial census is conducted on demographic and socio-economic characteristics of the population. The present study is limited to a period extending from 1991 to 2011. The study has conducted a comparative analysis of agricultural labourers based on secondary data obtained from Primary Census Abstracts for census years of 1991 and 2011. The year 1991 was taken as a base year because after 1991, the state experienced a dramatic fall in the proportion of agricultural labourers and a shift of agricultural workforce to non-agricultural sector, due to the implementation of New Economic Policy in India. Before 1991, Punjab had been experiencing the growth of agricultural labourers. The selection of 2011 as the terminal year is purely attributed to the availability of the latest census data, which was published in April 2013. This agricultural labour data is related to main workers, which is available at village and ward levels. The main workers are those workers who had worked for six months or more in a year.

Punjab had 46 tehsils in 1991 and the number increased to 77 in 2011, due to a change in the administrative structure. For making data comparable at tehsil level, the tehsil boundaries of 1991 have been adjusted to 2011 census for studying the change in spatial patterns of agricultural labour in the state. The adjustment of data of 1991 to 2011 has been done by segregating the village wise data of old tehsils to the new tehsils which otherwise was not possible in using the marginal workers' data which is not available at village and ward levels.

Agricultural labour percentages and averages have been calculated at the tehsil level. Maps have been prepared to give a clearer picture of the changes in the spatial distribution patterns of male and female agricultural labour in the state with the help of ArcGis 10.0 software.

\section{RESULTS AND DISCUSSIONS}

This section is devoted to analysing the determinants behind changes in the distribution patterns of male and female agricultural labour in the state during the study period. The adoption of new agricultural technology consisting of biochemical and mechanical inputs led to changes in labour use pattern in Punjab. Among the major changes, mechanization of farm operations has led to the displacement of agricultural labour especially unskilled females (Kahlon and Gill, 1967; Rao, 1975; Chand et al., 1985; Sidhu, 1991; GOP, 2004; Kaur, 2005; Sidhu et al., 2005; Husain, 2006; Jodhka, 2008; Narayanamoorthy et al., 2014; Reddy et al., 2014; Raju et al., 2015; Prasad and Kaur, 2017; NABARD, 2018; Singh and Goyal, 2019). Secondly, many parts of the state have registered a 
decline in employment and increase in the casualization of labour, due to the labour displacing techniques like weedicides and adoption of improved farm technology (Shah and Singh, 1970; Singh, 1995; Gill and Ghuman, 2001; Sidhu and Singh, 2004; Singh, 2009; Singh and Bhogal, 2016; Kaur et al., 2016; Singh and Singh, 2016; Rathi, 2020). The displacement of local labour especially attached labour, due to cheap migrant labour (Singh, 1995; Sidhu and Singh, 2004; GOP, 2004; Singh, 2012; Rathi, 2020); shift of local labour to non-farm employment (Gill and Ghuman, 2001; Kaur, 2005; Singh et al., 2007; Toor et al., 2007; Jodhka, 2008; Institute of Applied Manpower Research, 2013; FICCI, 2015; Singh, 2016; Rathi, 2020); migration of local labour especially scheduled castes to Gulf countries (GOP, 2004; Singh, 2016), conversion of small and marginal farmers to wage labourers (Singh and Bhogal, 2014) and decline in agricultural labour due to sub-division of landholdings (Jodhka, 2014; Uppal et al., 2018; Rathi, 2020) are other important changes that have taken place regarding the labour use scenario in the state.

However, a highly limited amount of work has been done by using a spatial approach in the abovementioned studies. Thus, the changes in the distribution patterns of male and female agricultural labour are analysed spatially in detail in the following discussion.

\subsection{Patterns of change in male agricultural labour in Punjab, 1991 and 2011}

Male agricultural labour as percent to main male workers has experienced a sharp decrease from $23.79 \%$ in 1991 to $13.96 \%$ in 2011 . Areas of decrease in male agricultural labour range from a decrease of $0.21 \%$ in Sultanpur Lodhi tehsil of Kapurthala district to $21.86 \%$ in SBS Nagar tehsil of the same district. Only 2 tehsils of Punjab have recorded an increase in male agricultural labour during 1991-2011. For analyzing the Spatio-temporal changes in male agricultural labour (Map 1), the state is divided firstly into areas of decrease and increase, which are further sub-divided based on the magnitude of change:

1. Areas of high decrease (above 10 percent)

2. Areas of low decrease (below 10 percent)

3. Areas of increase $(0.02-0.81$ percent $)$

\subsection{Areas of high decrease (above 10 percent)}

Areas of high decrease (above 10 percent) in the proportion of male agricultural labour are comprised of 37 tehsils of the state. Most of these tehsils form a large belt extending from northwestern to south-eastern central plains and adjoining parts of the northeastern sub-mountainous Punjab. Increase in mechanization (Narayanamoorthy et al., 2014; Reddy et al., 2014; Raju et al., 2015; Prasad and Kaur, 2017; NABARD, 2018), the shift of workforce from farm to non-farm sector (Institute of Applied Manpower Research, 2013; FICCI, 2015; Singh, 2016; Rathi, 2020) and sub-division of landholdings (Jodhka, 2014; Uppal et al., 2018; Rathi, 2020) have led to a high decrease in agricultural labour in these parts of the state.

\subsection{Areas of low decrease (below 10 percent)}

A low decrease (below 10 percent) has occurred over 38 tehsils of the state, due mainly to seasonality and casualization of farm operations (Kaur et al., 2016; Singh and Bhogal, 2016; Singh and Singh, 2016; Rathi, 2020). It varies from a $0.21 \%$ in Sultanpur Lodhi tehsil to $9.97 \%$ in Barnala tehsil of Punjab. Broadly, the western half of Punjab recorded a lesser decline because agriculture in these parts is still the major employer. The lower levels of literacy, relatively larger size of holdings make the operations viable and higher amount of labour are employed for growing the labour-intensive crops like cotton and paddy. In Sultanpur Lodhi, the decrease has been negligible due to the reason that farmers are into growing vegetables especially potato, watermelon and muskmelon. The Kamboj farmers in this part of the state are particularly known for vegetable farming and they are continuing with this practice. 


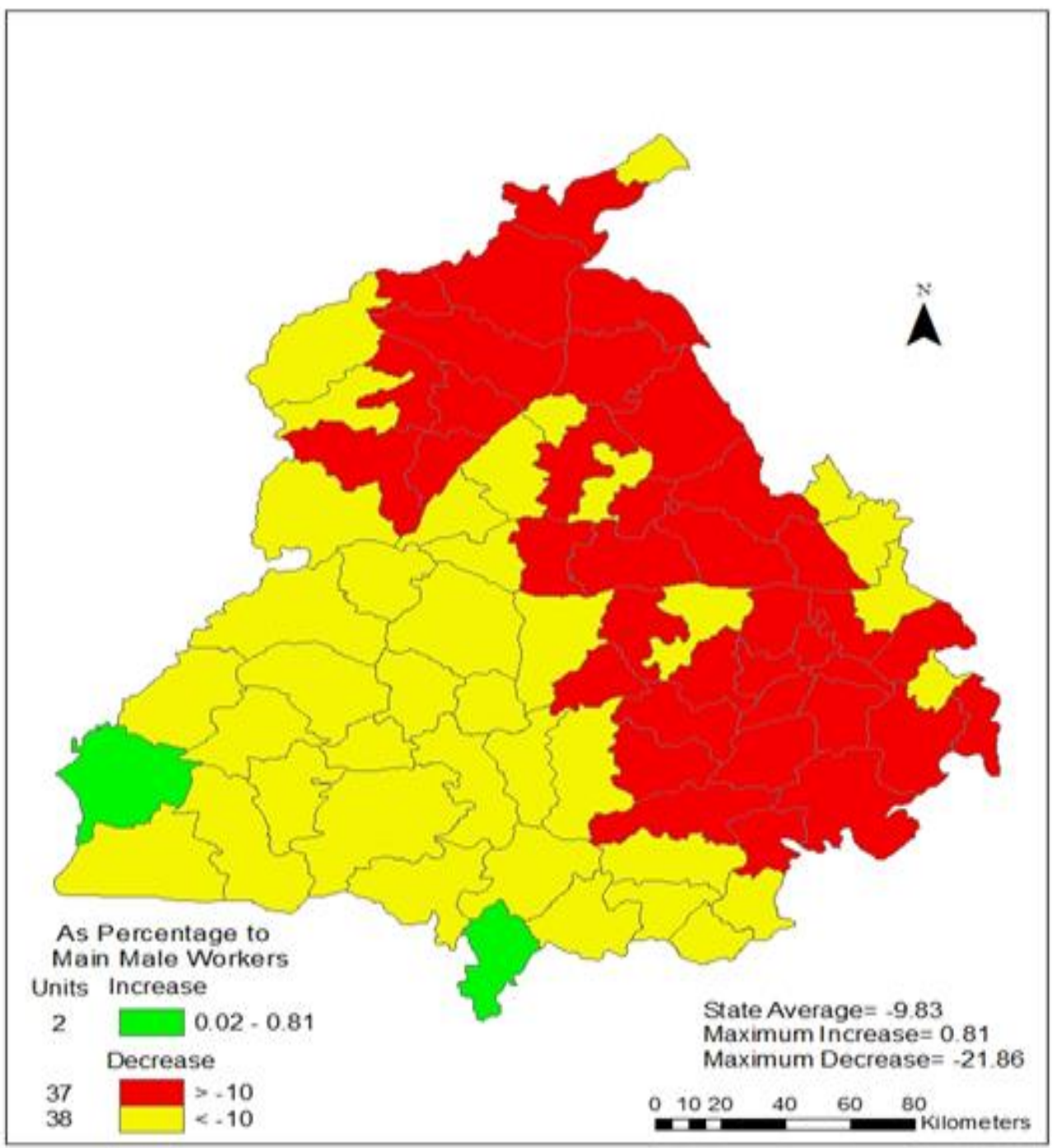

Figure 1: Tehsil level Spatio-temporal changes in the patterns of male agricultural labour from 1991-2011 in Punjab state

\subsection{Areas of increase $(0.02-0.81$ percent $)$}

An increase in the proportion of male agricultural labour has been witnessed in a small area, covering only two tehsils namely Fazilka $(0.81 \%)$ and Sardulgarh $(0.02 \%)$. Depeasantization of small and marginal farmers due to their non-viability under modern capital intensive farming is mainly responsible for the increase in male agricultural labour in many areas of the state (Singh and Bhogal, 2014).

\subsection{Patterns of change in female agricultural labour in Punjab, 1991 and 2011}

The proportion of female agricultural labour as percent to main female workers was $24.36 \%$ in 1991 which decreased to $12.99 \%$ in 2011 . This decrease in female agricultural labour $(11.37 \%)$ is comparatively higher than the decrease in male agricultural labour (9.83\%). Map 2 shows the Spatio-temporal changes which have taken place in the state. The decline in percentage points varies from 0.07 in Raikot tehsil of Ludhiana district in the centre to 56.66 in Patran tehsil of Patiala district in the south-east. For analyzing the spatial pattern of change of female agricultural labour since 1991, tehsils have been categorized into areas as follows: 
1. Areas of high decrease (above 10 percent)

2. Areas of low decrease (below 10 percent)

3. Areas of increase $(0.21-7.62$ percent $)$

\subsection{Areas of high decrease (above 10 percent)}

A high decrease of above $10 \%$ in female agricultural labour is a feature of 37 tehsils. These cover southwestern parts of the state falling over Firozpur, Fazilka, Muktsar, Faridkot, Moga, Bathinda and Mansa districts. A pocket of 13 tehsils of Taran Taran, Amritsar, Kapurthala, Jalandhar and Ludhiana districts spreading over central-western parts of central plains; and Dasua tehsil of Hoshiarpur district of the northeast sub-mountainous region also come under this category. The requirement of only male-specific mechanized labour in most of the agricultural practices caused the decrease of female agricultural labour in the state (Prasad and Kaur, 2017; NABARD, 2018; Singh and Goyal, 2019). The wide coverage of Atta Dal Scheme of the state government has also contributed towards the decrease of female labour in the agricultural operations. Under this scheme, landless below poverty line families get free wheat and pulses on monthly basis, which indirectly stopped the female labour for working on meagre wage rates in agricultural operations and finding higher wage rate work in the non-farm sectors i.e. factories. Also general shift of scheduled castes, due to migration of many male and female agricultural labourers to other occupations in Gulf and South-eastern Asian countries due to improvement in their economic conditions partly explains the decline in their proportion as agricultural labourers (GOP, 2004; Singh, 2016).

\subsection{Areas of low decrease (below 10 percent)}

A low decrease of below 10\% in female agricultural labour is noted in 31 tehsils of Punjab. All these tehsils are scattered over the three agro-climatic zones of Punjab by covering areas adjacent to the pockets having a decrease of above $10 \%$ in female agricultural labour. Displacement of female agricultural labour due to male skilled mechanized farm practices (Singh and Goyal, 2019), the shift of female workforce to non-farm sectors and the use of labour displacing farm technologies have led to the decline in female agricultural labour in these areas as well.

\subsection{Areas of Increase $(0.21-7.62$ percent $)$}

There are 9 tehsils of the state which experienced an increase in the proportion of female agricultural labour during 1991 and 2011. These include Dera Baba Nanak, Sultanpur Lodhi, Payal, Khamanon, Fatehgarh Sahib and Nabha falling in central plains region; and Dharkalan, Nangal and Rupnagar tehsils in the northeastern sub-mountainous region. Cultivation of labour-intensive vegetables in flood plains areas of Dera Baba Nanak and Sultanpur Lodhi tehsils whereas increased demand of female agricultural labour due to the shift of male workforce to more lucrative non-farm sectors i.e. work in factories and industries in the remaining tehsils have led to increasing in their share. 


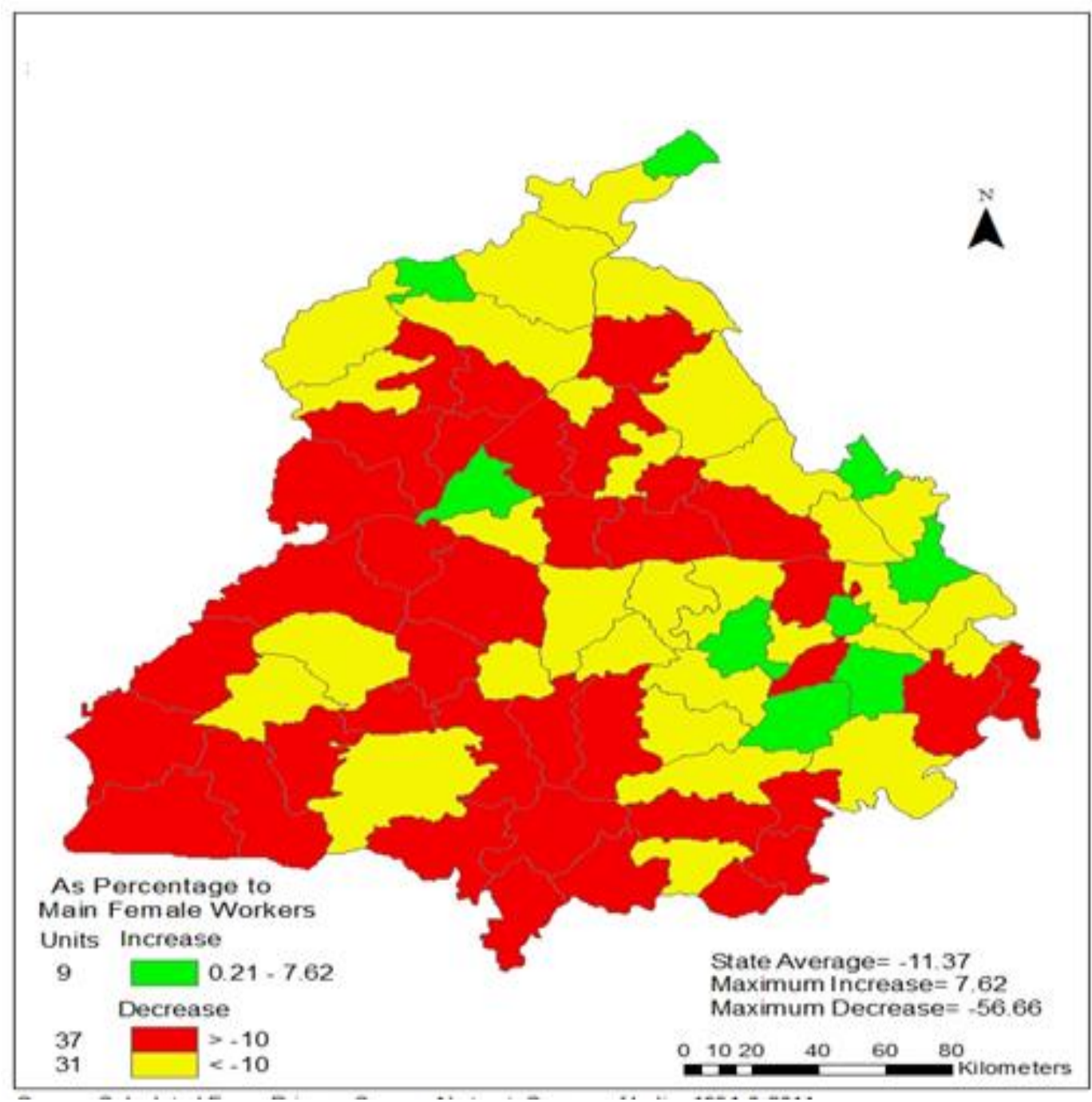

Figure 2: Tehsil level Spatio-temporal changes in the patterns of female agricultural labour from 1991-2011 in Punjab state

\section{CONCLUSIONS AND POLICY RECOMMENDATIONS}

The present study brought out that mechanization, casualization of major farm operations, availability of non-farm employment opportunities and sub-division of landholdings have been the major reasons for the decrease in the proportion of male agricultural labour in nearly the entire state during the study period. The reduced demand of agricultural labour due to requirement of only male-specific mechanized labour in most of the agricultural practices; lesser interest to work on farms due to the wide coverage of social welfare schemes like Atta Dal and improving socioeconomic conditions especially of scheduled castes, due to their migration to Gulf and south-east Asian nations for higher incomes have caused a significant decrease in the proportion of female agricultural labour in most parts of the state. This decrease of female agricultural labour is more than the decrease of male agricultural labour which shows that changing the agrarian structure of Punjab has affected mainly female agricultural labour in the state. On the other hand, there are areas in the central plains and north eastern sub-mountainous region which have seen an increase in the female agricultural labour due to female labour intensive operations of vegetable farming and 
increasing demand of female agricultural due to the non-availability of male agricultural labour who prefers to work in the urban and industrial sectors.

In light of farm mechanization induced agricultural development, displacement of agricultural labour from many farm operations and the shift towards higher wages in the non-farm sectors, there is an urgent need of a policy to enhance their employability in non-farm occupations under medium, small and micro enterprises (MSME) through short term skill programs especially in the central plains region of the state. To curb the displacement of female agricultural labour which was more than males, the women labourers must be given some kind of monetary and technical help to work in the cultivation of labour intensive and high income earning vegetable farming by implementing state's crop diversification plan. Women friendly machinery should be developed to encourage their participation in mechanized farm operations particularly in the north-eastern submountainous region of Punjab. As recent literature revealed an acute shortage of agricultural labour during peak periods of farm operations, the suitable machinery must be provided especially to small and marginal farmers on custom hiring basis through cooperatives at an affordable cost in Punjab.

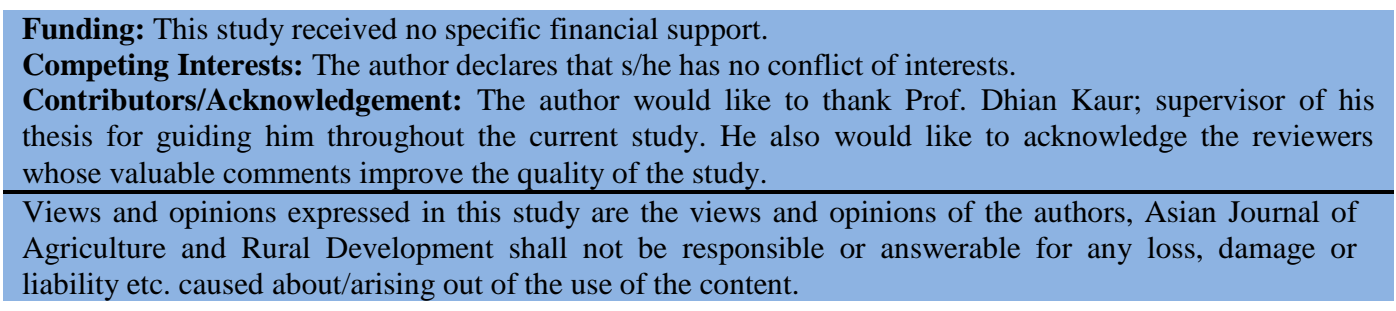

\section{References}

Bajwa, H. (2019). Labour shortage hits Punjab farm season. The New Indian Express. Retrieved on June 18, 2019, from https://www.newindianexpress.com/nation/2019/jun/18/labourshortage-hits-punjab-farm-season-1991578.html.

Bhalla, G. S., \& Singh, G. (2001). Indian agriculture. Sage Publication, New Delhi, India.

Bhardwaj, A. N. (2017). Shortage of labour troubles farmers. The Tribune. Retrieved on June 21, 2017, from https://www.tribuneindia.com/news/archive/jalandhar/shortage-of-labourtroubles-farmers-433006.

Billings, M. H., \& Singh, A. (1970). Mechanisation and rural employment with some implications for rural income distribution. Economic and Political Weekly, 5(26), 61-69.

Business Standard (2013). Punjab's farm, industry face labour shortage. Business Standard. Retrieved on June 21, 2017, from https://www.businessstandard.com/article/companies/punjab-s-farm-industry-face-labour-shortage108061500023 1.html.

Census of India. (1991). Primary census abstract. Registrar General of India. New Delhi, India.

Census of India. (2011). Primary census abstract. Registrar General of India. New Delhi, India.

Chaba, A. A. (2014). Despite labour shortage, not many takers for paddy transplanter. The Indian Express. Retrieved on June 21, 2017, from https://indianexpress.com/article/india/indiaothers/despite-labour-shortage-not-many-takers-for-paddy-transplanter/

Chadha, G. K. (1986). The state and rural economic transformation: the case of punjab, 19501985. Sage Publications, New Delhi, India.

Chand, R. (2019). Transforming agriculture for challenges of $21^{\text {st }}$ century. 102 annual conference of Indian economic association (IEA), 27-29 December 2019 (pp. 1-23). Surat: Indian Economic Association (IEA). Retrieved on March 30, 2020, from https://niti.gov.in/sites/default/files/2020-01/Presidential_Address.pdf.

Chand, R., Sidhu, D. S., \& Kaul, J. L. (1985). Impact of agricultural modernisation on labour use pattern in punjab with special reference to women labour. Indian Journal of Agricultural Economics, 40(3), 252-258. 
Chand, R., Srivastava, S., \& Singh, J. (2017). Changes in rural economy of India, 1971 to 2012: lessons for job-led growth. Economic and Political Weekly, 53(52), 64-71.

Dheer, G. (2012). Punjab farmers undergo 'labour pains'. Deccan Herald. Retrieved on June 21, 2017, from https://www.deccanherald.com/content/258009/punjab-farmers-undergolabour-pains.html.

Dutta, S. (2012). Green revolution revisited: the contemporary agrarian situation in punjab, India. Social Change, 42(2), 229-247.

Federation of Indian Chambers of Commerce \& Industry (FICCI). (2015). Labour in indian agriculture: a growing challenge. Mumbai: Klynveld Peat Marwick Goerdeler (KPMG) India Private Limited. Retrieved March 11, 2017, from http://ficci.in/spdocument/20550/FICCI-agri-Report\%2009-03-2015.pdf.

Ghuman, R. S. (2005). Rural non-farm employment scenario: reflections from recent data in punjab. Economic and Political Weekly, 50(41), 4473-4480.

Gill, M. S. (2018). Labour shortage shoots up paddy plantation cost. The Tribune. Retrieved on June 21, 2018, from https://www.tribuneindia.com/news/archive/amritsar/labour-shortageshoots-up-paddy-plantation-cost-608436.

Gill, S. S., \& Ghuman, R. S. (2001). Changing agrarian relations in india: some reflections from recent data. Indian Journal of Labour Economics, 44(4), 809-826.

GOI - Government of India (2019). NSO periodic labour force survey, 2017-18. New Delhi: National Statistical Office (NSO), Ministry of Statistics and Programme Implementation.

GOP - Government of Punjab (2004). Human development report. Government of Punjab, Chandigarh, India.

Grewal, S. S., \& Kahlon, A. S. (1974). Factors influencing labour employment on punjab farms. Agricultural Situation in India, 29(1), 3-5.

Gupta, P. (2019). NSSO survey reveals positive shift; jobs moving from farming to manufacturing, services. Financial Express. Retrieved on March 20, 2020, from https://www.financialexpress.com/: https://www.financialexpress.com/economy/surplusrural-workforce-shifting-from-agriculture-to-services-plfs-jobs-report-reveals-positiveswitch/1600637/.

Husain, M. (2006). Systematic agricultural geography. Rawat Publications, Jaipur, India.

Institute of Applied Manpower Research (IAMR). (2013). Rural non-farm employment: a study of Punjab. Planning Commission, Governmnet of India, New Delhi, India.

Jodhka, S. (2014). Changing face of rural India. Economic and Political Weekly, 49(14), 28-31.

Jodhka, S. S. (2008). The decline of agriculture. In S. K. Bhaumik. Reforming Indian Agriculture (pp. 96-116). New Delhi: Sage Publications.

Johl, S. S. (1975). Gains of the green revolution: how they have been shared in Punjab. The Journal of Development Studies, 11(3), 178-189.

Kahlon, A. S., \& Gill, D. S. (1967). A case of mechanising selected agricultural operations in Punjab. Agriculture Situation in India, 21(12), 1085-1088.

Kaur, A. P., Singh, J., Raju, S. S., \& Srivastava, S. K. (2016). Dynamics of labour and machine energy use in punjab agriculture. In S. Ahmed, \& S. Ismail, Energy, Economy and Sustainable Development (pp. 276-289). New Delhi: Bloomsbury Publisher India.

Kaur, M., Singh, S., Singh, J., Singh, J. M., Kingra, H. S., \& Sachdeva, J. (2018). District-wise cost of cultivation of important crops in Punjab. Department of Economics and Sociology. Ludhiana: Punjab Agricultural University. Retrieved March 20, 2020, from http://www.pbplanning.gov.in/pdf/COCbriefreport.pdf.

Kaur, R. (2005). Economic reforms, inter-state labour migration and employment pattern in rural Punjab, Ph.D Thesis (unpublished). Department of Sociology. Panjab University, Chandigarh, India.

Kumar, B. L. (1996). Changes in the composition of rural labour force: some evidence from a village resurvey. Indian Journal of Labour Economics, 39(4), 809-816.

Laxminarayan, H. (1982). Impact of agricultural development on employment: a case study of Punjab. Developing Economies, 20(1), 40-51. 
Narayanamoorthy, A., Bhattarai, M., Suresh, R., \& Alli, P. (2014). Farm mechanisation, MGNREGS and labour supply nexus: a state-wise panel data analysis on paddy and wheat crop. Indian Journal of Agricultural Economics, 69(3), 320-335.

National Bank for Agriculture and Rural Development (NABARD). (2018). Sectoral paper on farm mechanization. Mumbai: Farm Sector Policy Department, NABARD Head Office. $\begin{array}{lllll}\text { Retrieved } \quad \text { M } & \text { 20, } & \text { 2020, }\end{array}$ https://www.nabard.org/auth/writereaddata/file/NSP\%20Farm\%20Mechanisation.pdf.

Prasad, S. B., \& Kaur, K. (2017). Economic, social and environmental analysis for punjab agriculture. International Journal of Agriculture Sciences, 9(31), 4451-4455.

Raju, S. S., Suresh, A., Chand, R., \& Chauhan, S. (2015). Pattern and trend in labour use in indian agriculture: an analysis across major crops and states. Economic Affairs, 60(1), 99-108. doi:10.5958/0976-4666.2015.00014.5.

Randhawa, M. S. (1974). Green revolution: a case study of punjab. Vikas Publishing House, New Delhi, India.

Rangi, P. S., \& Sidhu, M. S. (2004). New farm technology and changing structure of agricultural labour employment in Punjab. Man and Development, 26(3), 61-80.

Rao, C. H. (1975). Technological change and distribution of gains in Indian Agriculture. New Delhi: MacMillan Company of India Ltd.

Rathi, A. (2020). Is Agrarian Resilience limited to Agriculture? Investigating the "farm" and "nonfarm" processes of Agriculture Resilience in the rural. Journal of Rural Studies, Article in Press. doi:10.1016/j.jrurstud.2019.12.015.

Reddy, A. A., Rani, C. R., \& Reddy, G. P. (2014). Labour scarcity and farm mechanisation: a cross state comparison. Indian Journal of Agricultural Economics, 69(3), 347-358.

Sahay, G. R. (2010). Globalisation, Liberalisation and Agrarian Distress: A study of Suicides Among Farmers in India. 6th Global Labour University Conference, held from 14-16 September. Berlin. Retrieved December 30, 2019, from https://www.global-labouruniversity.org/fileadmin/GLU_conference_2010/papers/51._Globalisation_Liberalisation and_Agrarian_Distress..pdf.

Shah, S. L., \& Singh, L. R. (1970). Impact of new technology on rural employment in northwestern uttar pradesh. Indian Journal of Agricultural Economics, 25(3), 29-33.

Sharma, A. (2018). Punjab Labour Shortage-Rising scarcity of farm workers pushes up production cost, inclination towards machine farming. First Post. Retrieved September 14, 2018, from https://www.firstpost.com/india/punjab-labour-shortage-rising-scarcity-of-farm-workerspushes-up-production-cost-inclination-towards-machine-farming-5183551.html.

Sidhu, H. S. (1991). Agricultural development and rural labour: a case study of punjab and haryana. New Delhi: Concept Publishing Company, India.

Sidhu, R. S., \& Singh, S. (2004). Agricultural wages and employment in Punjab. Economic and Political Weekly, 39(37), 11-17.

Sidhu, R. S., Bhullar, A. S., \& Joshi, A. S. (2005). Income, employment and productivity growth in the farming sector of punjab: some issues. Journal of Indian School of Political Economy, $7(1 \& 2), 59-72$.

Singh, G. (2015). Labour shortage irks farmers. The Tribune. Retrieved on June 21, 2017, from https://www.tribuneindia.com/news/archive/jalandhar/labour-shortage-irks-farmers-97041.

Singh, G., \& Singh, K. (2016). Employment patterns among agricultural labourers in rural punjab. Social Change, 46(3), 409-427. doi:10.1177/0049085716654815.

Singh, J., \& Goyal, K. (2019). Employment status of women in rural punjab: dwindling trends. Economic Affairs, 64(2), 281-290. doi:10.30954/0424-2513.2.2019.2.

Singh, L., Singh, I., \& Ghuman, R. S. (2007). Changing character of rural economy and migrant labour in punjab. Retrieved on December 26, 2018, from www.mpra.ub.unimuenchen.de/6420/.

Singh, M. (1995). Capitalist agriculture and freedom of labour. Economic and Political Weekly, 30(52), 3390-3393. 
Singh, M. (2012). Preference for migrant agricultural labour in punjab. Economic \& Political Weekly, 47(29), 27-28.

Singh, P. (2016). Agricultural labor shortage in punjab: a case study of muktsar district. Riga: LAP LAMBERT Academic Publishing. Retrieved December 20, 2019, from https://www.amazon.com/Agricultural-Labor-Shortage-Punjab-District/dp/3330003219.

Singh, S. (2009). Survival of agricultural labour in punjab: a burning question. Economic and Political Weekly, 44(29), 24-25.

Singh, S., \& Bhogal, S. (2014). Depeasantization in punjab: status of farmers who left farming. Current Science, 106(10), 1364-1368.

Singh, S., \& Bhogal, S. (2016). The forgotten ones: looking at agricultural labourers. The Tribune. Retrieved on March 21, 2019, from https://www.tribuneindia.com/news/comment/theforgotten-ones-looking-at-agricultural-labourers-230994.

Sood, A. (2016). Paddy season begins today, farmers feel labour pangs. The Tribune. Retrieved on June 21, 2017, from https://www.tribuneindia.com/news/archive/features/paddy-seasonbegins-today-farmers-feel-labour-pangs-251807.

Toor, M. S., Bhullar, A. S., \& Kaur, I. (2007). Agriculture led diversification and labour use in punjab: potentials and constraints. The Indian Journal of Labour Economics, 50(4), 737 746.

Uppal, A., Kaur, R., \& Singh, G. (2018). Globalisation and exclusion of landless rural labour in india with special reference to Punjab. $35^{\text {th }}$ IARIW General Conference-Copenhagen, held on August 22, 2018. Copenhagen: International Association for Research in Income and Wealth, Canada. Retrieved on February 20, 2020, from http://www.iariw.org: http://www.iariw.org/copenhagen/uppal.pdf.

Usami, Y., \& Rawal, V. (2018). Changes in the structure of employment in india: study using agecohort analysis of NSS Data for 2004-05 and 2011-12. New Delhi: The Society for Social and Economic Research (SSER). Retrieved March 18, 2020, from http://archive.indianstatistics.org/sserwp/sserwp1802.pdf.

Visaria, P., \& Basant, R. (1994). Non-agricultural employment in india: trends and prospects. New Delhi: Sage Publications, India. 